\title{
Phosphorylation of Mitogen-Activated Protein Kinase by One-Trial and Multi-Trial Classical Conditioning
}

\author{
Terry Crow, ${ }^{1}$ Juan-Juan Xue-Bian, ${ }^{1}$ Vilma Siddiqi, ${ }^{1}$ Yuan Kang, ${ }^{2}$ and Joseph T. Neary ${ }^{2,3}$ \\ ${ }^{1}$ Department of Neurobiology and Anatomy, University of Texas Medical School at Houston, Houston, Texas 77225, and \\ 2Research Service, Veterans Affairs Medical Center and ${ }^{3}$ Departments of Pathology, and Biochemistry and Molecular \\ Biology, University of Miami School of Medicine, Miami, Florida 33125
}

\begin{abstract}
The pathway supporting the conditioned stimulus (CS) is one site of plasticity that has been studied extensively in conditioned Hermissenda. Several signal transduction pathways have been implicated in classical conditioning of this preparation, although the major emphasis has been on protein kinase C. Here we provide evidence for the activation and phosphorylation of a mitogen-activated protein kinase (MAPK) pathway by one-trial and multi-trial conditioning. A one-trial in vitro conditioning procedure consisting of light (CS) paired with the application of 5-HT results in the increased incorporation of ${ }^{32} \mathrm{PO}_{4}$ into proteins detected with two-dimensional gel electrophoresis. Two of the phosphoproteins have molecular weights of 44 and $42 \mathrm{kDa}$, consistent with extracellular signal-regulated protein kinases (ERK1 and ERK2). Phosphorylation of the 44 and $42 \mathrm{kDa}$ proteins by one-trial conditioning was inhibited by pretreatment with PD098059, A MEK1 (ERK-Activating kinase) inhibitor. Assays of ERK activity with brain myelin basic protein
\end{abstract}

as a substrate revealed greater ERK activity for the group that received one-trial conditioning compared with an unpaired control group. Western blot analysis of phosphorylated ERK using antibodies recognizing the dually phosphorylated forms of ERK1 and ERK2 showed an increase in phosphorylation after one-trial conditioning compared with unpaired controls. The increased phosphorylation of ERK after one-trial conditioning was blocked by pretreatment with PD098059. Hermissenda that received 10 or 15 conditioning trials showed significant behavioral suppression compared with pseudo-random controls. After conditioning and behavioral testing, the conditioned animals showed significantly greater phosphorylation of ERK compared with the pseudo-random controls. These results show that the ERK-MAPK signaling pathway is activated in Pavlovian conditioning of Hermissenda.

Key words: Pavlovian conditioning; MAPK pathway; signal transduction; cellular excitability; ERK cascade; Hermissenda
Several cellular signaling pathways have been implicated in studies of neuronal plasticity underlying learning and memory. The activation of cAMP-dependent protein kinase is a requirement for long-term facilitation in Aplysia and long-term retention of conditioning in Drosophila (for review, see DeZazzo and Tully, 1995; Bailey et al., 1996). In Hermissenda the protein kinase C (PKC) pathway is involved in the induction of short-term plasticity (Matzel et al., 1990; Crow et al., 1991; Schuman and Clark, 1994) and changes in excitability associated with multi-trial Pavlovian conditioning (Farley and Auerbach, 1986; Neary et al., 1986; Farley and Schuman, 1991; Frysztak and Crow, 1997). One-trial conditioning in Hermissenda produces long-term behavioral suppression (Crow and Forrester, 1986) and short- and long-term enhancement (STE and LTE, respectively) in sensory neurons of the conditioned stimulus (CS) pathway (Crow and Forrester, 1991, 1993). Short- and long-term memory after conditioning can be dissociated based on the role of mRNA synthesis, protein synthesis, and the contribution of PKC (Crow and Forrester, 1990, 1991, 1993; Crow et al., 1997). Recent support for the independence of short- and long-term memory stems from studies showing that downregulation of PKC or pretreatment with kinase inhibitors blocked the induction of STE; however,

\footnotetext{
Received Dec. 31, 1997; revised Feb. 20, 1998; accepted Feb. 23, 1998.

This work was supported by National Institute of Mental Health Grants MH40860 and MH01363 to T.C.

Correspondence should be addressed to Terry Crow, Department of Neurobiology and Anatomy, University of Texas Medical School, P.O. Box 20708, Houston, TX 77225.

Copyright (C) 1998 Society for Neuroscience $\quad 0270-6474 / 98 / 183480-08 \$ 05.00 / 0$
}

LTE was normally expressed (Crow and Forrester, 1993). These results indicate that other signaling pathways contribute to plasticity associated with short- and long-term memory in Hermissenda. A mitogen-activated protein kinase (MAPK) pathway involving extracellular signal-regulated protein kinase (ERK) has been implicated in cellular growth and plasticity (for review, see Neary, 1997; Robinson and Cobb, 1997). MAPK activation and phosphorylation have been previously shown for LTP induction (English and Sweatt, 1996) and long-term facilitation of cultured Aplysia neurons (Martin et al., 1997); however, MAPK phosphorylation has not been previously reported in Pavlovian conditioning. In this report, we provide evidence for the contribution of ERK in classical conditioning of Hermissenda. We show that in vitro one-trial conditioning and multi-trial Pavlovian conditioning result in the activation and phosphorylation of ERK1 and ERK2.

Portions of this research have appeared previously in abstracts (Xue-Bian et al., 1997a,b)

\section{MATERIALS AND METHODS}

Experimental paradigm. Adult Hermissenda crassicornis obtained from Sea-Life Supply (Sand City, CA) were used in the experiments. Animal maintenance was as described previously (Crow and Forrester, 1991). For phosphorylation studies and kinase assays, the circumesophageal nervous systems were removed, and the eyes, including proximal optic nerve, were isolated. As shown previously, the eye is a discrete structure containing five photoreceptors (Alkon and Fuortes, 1972). To minimize potential animal-to-animal variability in ${ }^{32} \mathrm{PO}_{4}$ uptake, eyes from three to four animals were used for each experimental treatment and for control procedure in each experimental replication. The isolated eyes were placed into vials containing artificial seawater (ASW) at $15^{\circ} \mathrm{C}$ having the 
following composition (in $\mathrm{mM}$ ): $460 \mathrm{NaC} 1,10 \mathrm{KC} 1,10 \mathrm{CaCl}_{2}$, and 55 $\mathrm{MgCl}_{2}$, buffered with 10 HEPES, and adjusted to $\mathrm{pH} 7.6$ with dilute $\mathrm{NaOH}$. The isolated eyes were randomly distributed to the different treatment groups. The vials containing the isolated eyes were maintained at $15^{\circ} \mathrm{C}$ in a dark room to provide a $12 \mathrm{~min}$ period of dark adaptation before applying the different treatments.

Conditioning procedure and baseline test of phototactic behavior. The details of the conditioning procedures and methods for testing phototactic behavior have been described previously in detail (Crow and Alkon, 1978; Crow and Offenbach, 1983; Crow, 1985) and will be described only briefly in this report. Animals were tested before conditioning to determine baseline latencies to initiate locomotion in response to a test light. Animals that did not respond within a $15 \mathrm{~min}$ criterion period during the pretraining measurements were not used in the conditioning experiments. Animals were placed into 228-mm-long glass tubes filled with ASW. A foam plug inserted through an opening confined the animal to one end of the tube. The tubes were attached by spring clips to a modified turntable enclosed in an incubator maintained at $15^{\circ} \mathrm{C}$. Animals were dark-adapted for $12 \mathrm{~min}$ before testing phototactic behavior. A light spot $\left(10^{-4} \mathrm{~W} / \mathrm{cm}^{2}\right.$, white light $)$ was projected onto the center of the turntable, illuminating a circular area $15-16 \mathrm{~cm}$ in diameter, and the elapsed times to initiate locomotion in the presence of the test light were recorded. Previous research has shown that the increase in the time taken by the animals to locomote into a test light can be accounted for by an increase in the latency to initiate locomotion (Crow and Offenbach, 1983). After baseline measurements, animals were randomly assigned to conditioned and pseudo-random control groups. The conditioning phase consisted of 10 or 15 trials of the $10 \mathrm{sec}$ CS (light) and the unconditioned stimulus (US, high-speed rotation) with an average intertrial interval of 3-4 min. The intensity of the CS was the same as that for the test light used to establish baseline responding of phototactic behavior during the pretest condition. The pseudo-random control group received 10 or 15 trials of the CS and US programmed on explicitly unpaired schedules. For each conditioning session, both conditioned and pseudo-random control animals were selected from the same animal shipment. All animals received behavioral testing identical to the pretraining (baseline) test measurement for phototaxis $10 \mathrm{~min}$ after the last conditioning trial. Animals that did not initiate locomotion in the presence of the CS within $15 \mathrm{~min}$ during the post-test received a maximum latency score. Assessment of conditioning was determined by computing suppression ratios that compared post-training phototactic behavior with pretraining test scores. The ratio is expressed as $A /(A+B)$, where $A$ represents pretraining scores, and $B$ represents post-training scores.

The in vitro one-trial conditioning procedure consisted of the presentation of a 5 or $10 \mathrm{~min}$ period of light $\left(\sim 10^{-4} \mathrm{~W} / \mathrm{cm}^{2}\right.$; CS $)$ paired with $10^{-4}$ м 5-HT applied to the isolated eye-nerve preparations. After the conditioning trial preparations were washed, lysed, and frozen at $-80^{\circ} \mathrm{C}$. Control groups received one $5 \mathrm{~min}$ trial of light or one unpaired presentation of light $(10 \mathrm{~min})$ and the application of 5 -HT $\left(10^{-4} \mathrm{M}\right)$ using procedures described previously (Crow and Forrester, 1986). The onetrial conditioning procedure when applied in vivo has been shown to result in long-term (24 hr) behavioral suppression (Crow and Forrester, 1986).

Protein phosphorylation. For studies of protein phosphorylation after one-trial conditioning, the treatment and control groups were incubated for $2 \mathrm{hr}$ in ${ }^{32} \mathrm{PO}_{4}$. Previous work has shown that the incorporation of phosphate into protein is linear with respect to time for $1-4 \mathrm{hr}$ (Neary et al., 1981). The in vitro conditioning procedure consisted of a 5 min trial of light paired with $10^{-4}$ м 5-HT and was followed by a wash with ASW. The treatment group received the $2 \mathrm{hr}$ incubation in ${ }^{32} \mathrm{PO}_{4}$ followed by one-trial in vitro conditioning. The control groups received the $2 \mathrm{hr}$ incubation in the ${ }^{32} \mathrm{PO}_{4}$ followed by $5 \mathrm{~min}$ of light. The incubation solution consisted of $200 \mu \mathrm{l}$ of oxygenated ASW containing $11 \mathrm{~mm}$ glucose and $0.125 \mathrm{mCi}$ of ${ }^{32} \mathrm{PO}_{4}$ (carrier-free) (New England Nuclear). After the $2 \mathrm{hr}$ incubation the samples were quickly rinsed twice in an isotonic ice-cold wash solution (in mM: $460 \mathrm{NaCl}, 10 \mathrm{KCl}, 5 \mathrm{EDTA}$, and 100 Tris-HCl, pH 7.8). After the wash, samples were lysed in a modified lysis solution containing $9.2 \mathrm{M}$ urea, 2\% Nonidet P-40, 5\% $\beta$-mercaptoethanol, and $2 \%$ carrier ampholytes $(1.6 \% \mathrm{pH} 5-8,0.4 \% \mathrm{pH}$ $3.5-10)$ and stored frozen at $-80^{\circ} \mathrm{C}$.

Two-dimensional gel electrophoresis. Aliquots of the samples from the treatment and control conditions were analyzed by a horizontal system for two-dimensional gel electrophoresis (Pharmacia, Piscataway, NJ) using a first-dimension isoelectric focusing (IEF) gel with an immobilized $\mathrm{pH}$ gradient (4-7) and a precast SDS polyacrylamide (8-18\% linear gradient) second-dimension gel (Görg et al., 1988; Görg, 1991). For the first dimension, the IEF phase was conducted for a total of $58.5 \mathrm{kVhr}$. The gels were then equilibrated for $20 \mathrm{~min}$ in a solution containing $2 \%$ SDS, $50 \mathrm{~mm}$ Tris, $6 \mathrm{~m}$ urea, 9\% glycerol, and $65 \mathrm{~mm}$ DTT and placed on precast SDS polyacrylamide (gradient) gels for the second dimension. Electrophoresis in the second dimension was conducted for $1.65 \mathrm{kVhr}$. Gels were stained and fixed in $0.1 \%$ Coomassie brilliant blue in $50 \%$ trichloroacetic acid, destained in $7 \%$ acetic acid, and dried. Gel staining verified that approximately equivalent amounts of protein were applied to each gel. Autoradiographic exposures of the gels were performed using storage phosphor screens for $24 \mathrm{hr}$. Phosphor screens were computer scanned and analyzed using ImageQuant software (Molecular Dynamics, Sunnyvale, CA) for quantitative analysis. All samples were coded so that two-dimensional gel electrophoresis, autoradiographic exposures, phosphor screen scanning, and analysis were performed by individuals not knowing the previous experimental treatments of the samples, i.e., totally blind experimental procedure. Phosphoprotein molecular weights were estimated by comparison with prestained protein standards (Bio-Rad, Hercules, CA).

ERK phosphorylation. ERK phosphorylation was measured in preparations consisting of the eyes and proximal optic nerves after one-trial in vitro conditioning or in groups that received 10 or 15 conditioning trials. Control groups received an unpaired trial of light $(10 \mathrm{~min})$ and 5-HT (in vitro procedure) or 10 or 15 pseudo-random presentations of the CS and US. The activation of ERK was determined by immunoblotting using polyclonal antibodies raised against the dually phosphorylated and active epitope in ERK1/p44 and ERK2/p42 (antiactive MAPK; Promega, Madison, WI). To verify that approximately equal amounts of ERK were applied to each lane, identically prepared membranes were probed for total ERK1 and ERK2 (Santa Cruz Biotechnology, Santa Cruz, CA). The lysates from the different treatments were resolved in SDS polyacrylamide gels and transferred to polyvinylidene difluoride membranes. Membranes were blocked with $0.5 \%$ gelatin in Tris-buffered saline and Tween (TBST), $\mathrm{pH} 7.5,10 \mathrm{~mm}$ Tris buffer, $100 \mathrm{~mm} \mathrm{NaCl}$, and $0.1 \%$ Tween 20 or 5\% dry milk in TBST for $1 \mathrm{hr}$ at room temperature. The membranes were incubated in the primary antibody for $2 \mathrm{hr}$ at room temperature, washed, and incubated in the secondary antibody (antirabbit IgG connected with HRP) for $1 \mathrm{hr}$. The inmunocomplexes were detected with enhanced chemiluminescence reagent (Amersham, Arlington Heights, IL) following the manufacturer's procedures. The relative intensity of the immunoblotting on autoradiograms was quantified by using imaging densitometry on the output of a digital video camera attached to a microscope. Relative enzyme activation was determined by normalization of the density of images from phosphorylated ERK with the total ERK from parallel experiments from the same sample.

ERK assays. ERK activity was measured as described previously (Neary and Zhu, 1994). In brief, after the one-trial in vitro conditioning or unpaired control procedures, preparations were lysed in a buffer containing $20 \mathrm{~mm}$ Tris, $\mathrm{pH} 7.0,0.27 \mathrm{M}$ sucrose, $1 \mathrm{~mm}$ EDTA, $1 \mathrm{~mm}$ EGTA, $50 \mathrm{~mm} \mathrm{NaF}, 1 \mathrm{~mm}$ dithiothreitol, $1 \mathrm{~mm}$ sodium orthovanadate, 10 mM $\beta$ glycerophosphate, $5 \mathrm{~mm}$ sodium pyrophosphate, and $1 \%$ Triton $\mathrm{X}-100$. The lysates were centrifuged in a microfuge for $5 \mathrm{~min}$ at $4^{\circ} \mathrm{C}$. Aliquots of the supernatants $(20 \mu \mathrm{l})$ were assayed at $30^{\circ} \mathrm{C}$ for $20 \mathrm{~min}$ in a final reaction solution containing $10 \mu \mathrm{M}$ ATP $\left(0.2 \mu \mathrm{Ci}\left[\gamma^{32} \mathrm{P}\right] \mathrm{ATP}\right.$; New England Nuclear), $10 \mathrm{mM} \mathrm{MgCl} 2,1 \mu \mathrm{M}$ okadaic acid (LC Laboratories), and $0.33 \mathrm{mg} / \mathrm{ml}$ bovine brain myelin basic protein (Sigma, St. Louis, MO) in a final volume of $40 \mu \mathrm{l}$. Under these conditions, the reaction is linear with respect to time and enzyme concentration. Reactions were stopped by pipetting $20 \mu \mathrm{l}$ aliquots onto $1 \times 2 \mathrm{~cm}$ strips of phosphocellulose paper and immediately placing the strips in $75 \mathrm{~mm}$ phosphoric acid. Strips were washed for a minimum of $2 \mathrm{hr}$ and rinsed three times for 5 min each in $75 \mathrm{~mm}$ phosphoric acid and once in ethanol. Strips were dried and transferred to scintillation vials, and radioactivity was assessed by liquid scintillation counting. ERK activity was expressed as picomoles of ${ }^{32} \mathrm{P}$ transferred per minute per milligram of protein. Protein concentrations were determined by the modified Lowry procedure described by Peterson (1983) with bovine serum albumin as standard.

\section{RESULTS}

\section{Protein phosphorylation}

We examined changes in protein phosphorylation in the photoreceptors after the in vitro one-trial conditioning procedure. Previous studies have shown that conditioning results in the increased phosphorylation of several phosphoproteins associated 
Figure 1. Phosphate incorporation in 44 and $42 \mathrm{kDa}$ proteins from paired and control groups as analyzed by twodimensional gel electrophoresis. Laser prints of a storage phosphor screen scan showing ${ }^{32} \mathrm{PO}_{4}$ labeling of phosphoproteins after two-dimensional electrophoretic separation. The example shown on the top is from a group that received one 5 min conditioning trial of light paired with 5 -HT $\left(10^{-4}\right.$ M). The control group shown on the bottom received one $5 \mathrm{~min}$ trial of light. An increase in ${ }^{32} \mathrm{PO}_{4}$ incorporation was detected for the paired group compared with the controls.

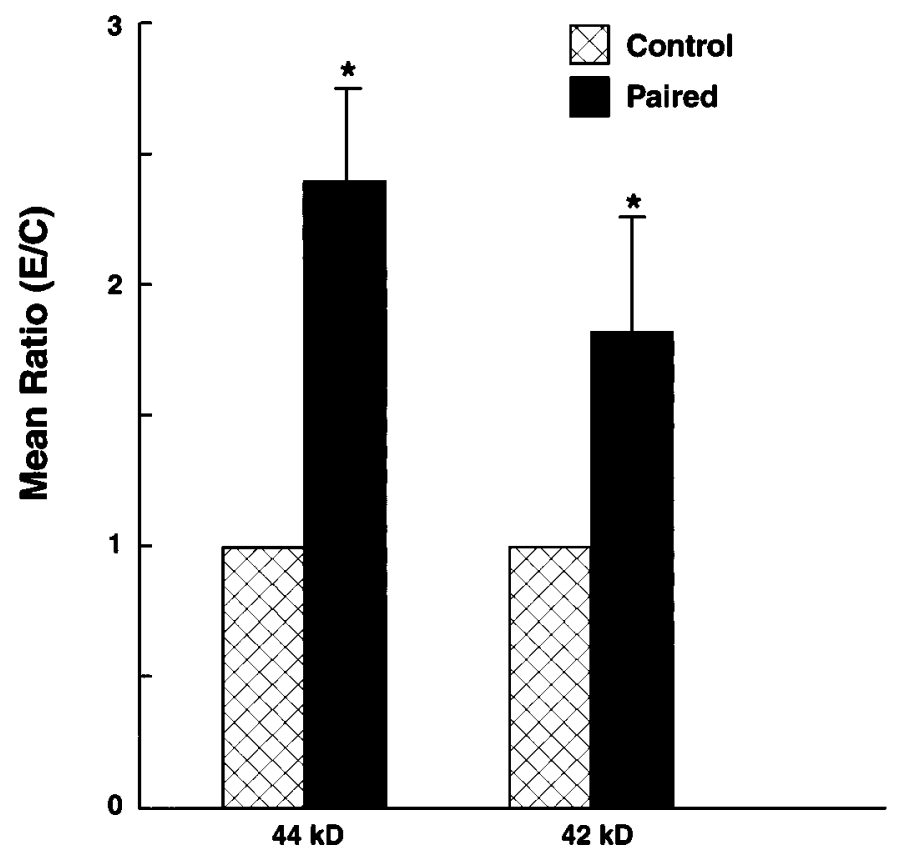

Figure 2. Group data $(n=7)$ showing mean \pm SEM E/C ratios of densitometric measurements for the 44 and $42 \mathrm{kDa}$ phosphoproteins after the one-trial conditioning procedure (paired light and 5-HT, $5 \mathrm{~min}$ ) and the light-only control $(5 \mathrm{~min})$. One-trial conditioning resulted in a significant increase in ${ }^{32} \mathrm{PO}_{4}$ incorporation for the 44 (mean $=2.4 \pm 0.3 ; p<$ $0.03)$ and $42($ mean $=1.8 \pm 0.4 ; p<0.05) \mathrm{kDa}$ phosphoproteins compared with the control groups.

with short- and long-term enhancement of excitability in lateral type B photoreceptors (Crow et al., 1996). In the present study we examined two additional phosphoproteins after one-trial conditioning with a molecular mass of 44 and $42 \mathrm{kDa}$. An example of ${ }^{32} \mathrm{PO}_{4}$ labeling of the 44 and $42 \mathrm{kDa}$ phosphoproteins after two-dimensional electrophoretic separation is shown in Figure 1. The animals that received one trial of light paired with 5-HT $\left(10^{-4} \mathrm{M}\right)$ showed a greater level of ${ }^{32} \mathrm{P}$ incorporation into the two phosphoproteins compared with the controls that received one trial of light (Fig. 1). The group data [mean \pm SEM experimental/control (E/C) ratio] shown in Figure 2 represents the quantitative analysis of the ${ }^{32} \mathrm{P}$ content of the 44 and $42 \mathrm{kDa}$ phosphoproteins from the conditioned group $(n=7)$ and light-only control group $(n=7)$, as determined by densitometry. A significant increase in protein phosphorylation relative to the light-only control groups was detected for the 44 (mean $=2.4 \pm 0.3 ; t_{(6)}=$ $2.7 ; p<0.03)$ and $42\left(\right.$ mean $\left.=1.8 \pm 0.4 ; t_{(6)}=2.4 ; p<0.05\right) \mathrm{kDa}$ phosphoproteins. These results show that two phosphoproteins with molecular masses consistent with ERK1 and ERK2 show an increased phosphorylation for the conditioned groups relative to the controls. In addition, the immunoblots of two-dimensional gels probed with a phosphotyrosine antibody (PY 20; Transduction Laboratories, Lexington, $\mathrm{KY}$ ) revealed two spots that comigrated with the 44 and $42 \mathrm{kDa}$ phosphoproteins as would be expected if these proteins are ERK1 and ERK2 (data not shown).

The phosphorylation studies suggest that the ERK signaling pathway may be involved in the cellular plasticity observed after one-trial conditioning. To further investigate the potential role of ERK in conditioning, we treated preparations with PD098059, A MEK-1 (ERK-activating kinase) inhibitor (Dudley et al., 1995). The phosphorylation of four phosphoproteins from conditioned and control animals was examined after 30 min pretreatment with PD098059 $(50 \mu \mathrm{M})$. The group data (mean \pm SEM E/C ratio) shown in Figure 3 represents the densitometric analysis of the four phosphoproteins after conditioning that were pretreated with PD098059. Two of the phosphoproteins, 55 and $29 \mathrm{kDa}$, have been shown to exhibit an increase in ${ }^{32} \mathrm{P}$ incorporation after the one-trial conditioning procedure (Crow et al., 1996). As shown in Figure 3, pretreatment with PD098059 resulted in a significant decrease in ${ }^{32} \mathrm{P}$ incorporation for the conditioned groups $(n=6)$ relative to the light-only control groups $(n=6)$ for the $44\left(\right.$ mean $\left.=0.59 \pm 0.17 ; t_{(5)}=2.4 ; p<0.05\right)$ and $42($ mean $=$ $\left.0.34 \pm 0.04 ; t_{(5)}=15.6 ; p<0.001\right) \mathrm{kDa}$ phosphoproteins. In contrast to the results for the 44 and $42 \mathrm{kDa}$ phosphoproteins, the 55 and $29 \mathrm{kDa}$ phosphoproteins were not significantly affected by the 30 min pretreatment with PD098059. However, both the 55 and $29 \mathrm{kDa}$ phosphoproteins were shown to exhibit increased ${ }^{32} \mathrm{P}$ incorporation with one-trial conditioning. These results show that an inhibitor of the ERK activator blocks increased protein phosphorylation of two phosphoproteins hypothesized to be ERK1 and ERK2. In addition, these findings support the specificity of the actions of the inhibitor because most phosphoproteins, including the 55 and $29 \mathrm{kDa}$ phosphoproteins, were not significantly affected by PD098059.

\section{Assay of ERK activity in conditioned and unpaired controls}

The results of the experiments that examined the effects of the MEK1 inhibitor on protein phosphorylation suggest that the 44 and $42 \mathrm{kDa}$ phosphoproteins may be ERK1 and ERK2, respectively. To provide evidence for the activation of ERK after one-trial conditioning, we assayed ERK activity. We also examined the issue of pairing specificity of light and 5-HT by examining ERK activity in unpaired control groups. The group data (mean \pm SEM) shown in Figure 4 represent the ERK activity for 


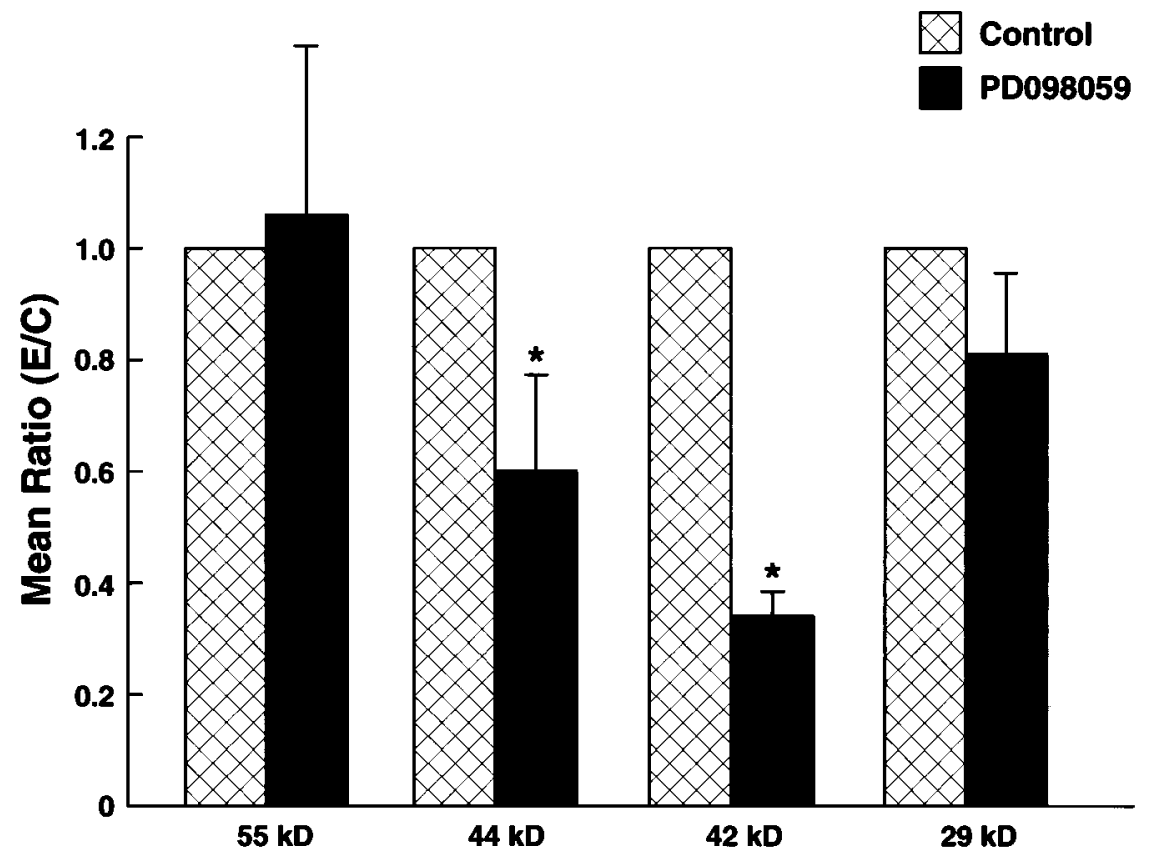

Figure 3. Group data $(n=6)$ showing mean \pm SEM $\mathrm{E} / \mathrm{C}$ ratios of densitometric measurements for four phosphoproteins examined after one-trial conditioning (paired light and 5-HT, $5 \mathrm{~min}$ ) and one-trial conditioning for a group pretreated with the MEK1 inhibitor PD098059 (50 $\mu \mathrm{M})$. Treatment with PD098059 before one-trial conditioning produced a significant reduction in ${ }^{32} \mathrm{PO}_{4}$ incorporation into the 44 (mean $=0.59 \pm 0.17 ; p<0.05)$ and 42 (mean $=$ $0.34 \pm 0.04 ; p<0.001) \mathrm{kDa}$ phosphoproteins relative to the conditioned group not treated with PD098059. In contrast, two other phosphoproteins (55 and 29 $\mathrm{kDa}$ ) in which phosphorylation has been shown to increase with one-trial conditioning were not affected by pretreatment with PD098059.

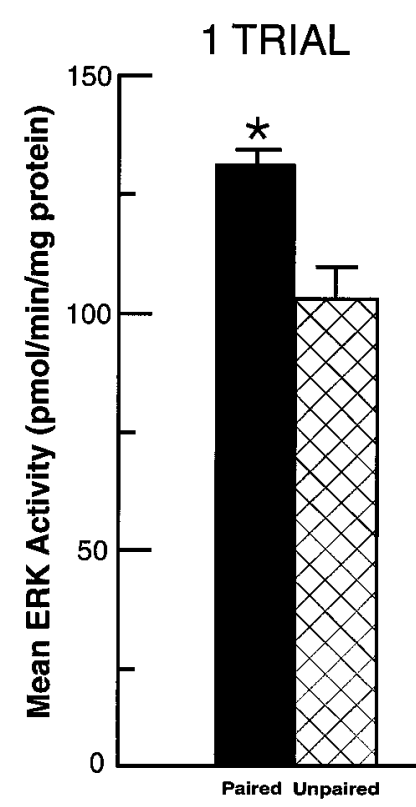

Figure 4. Group data showing mean \pm SEM ERK activity measured as phosphorylation of an ERK substrate, brain myelin basic protein. ERK activity for the paired group (mean $=130.7 \pm 3 ; n=6$ ) that received one trial of light and 5-HT was significantly greater than the unpaired group $($ mean $=102.7 \pm 6.7 ; n=3)$ that received one unpaired trial of light and 5-HT. * $p<0.001$.

the group that received one trial of paired light and 5-HT $(n=6)$ and control group that received one unpaired trial and light and 5-HT $(n=3)$. As shown in Figure 4, the conditioning trial resulted in a significant increase in ERK activity (mean $=130.7 \pm$ 3 ) compared with the unpaired control group (mean $=102.7 \pm$ $\left.6.7 ; t_{(7)}=3.8 ; p<0.001\right)$. The results provide further evidence for the involvement of ERK in one-trial conditioning.

\section{Western blot analysis of ERK}

To provide additional evidence for the role of active ERK in one-trial conditioning, we examined phosphorylation of ERK using antibodies recognizing the dually phosphorylated forms of ERK1 and ERK2 compared with antibodies recognizing total nonphosphorylated and phosphorylated ERK1 and ERK2. Immunoblot analysis with the antibody recognizing total ERK revealed a single band consistent with the molecular weight of ERK. Moreover, a pretreatment control with an ERK-blocking peptide (Santa Cruz Biotechnology) prevented antibody staining on Western blots. This result supports the specificity of the ERK signal observed on the immunoblots. As shown in Figure $5 A$, one conditioning trial of light paired with 5 -HT $\left(10^{-4} \mathrm{M}\right)$ resulted in an increased amount of phosphorylated ERK compared with controls that received one unpaired trial of light and 5-HT, although the total ERK was equivalent in these two conditions (Fig. 5A). As shown in Figure 5B, samples pretreated with PD098059 $(50 \mu \mathrm{M}) 30 \mathrm{~min}$ before the presentation of the conditioning trial did not show the typical increased phosphorylation of ERK as exhibited by the group that received one trial of light and 5-HT (see Fig. 5B). The group data from three independent experiments were consistent with the example shown in Figure $5 B$. Pretreatment before conditioning with PD098059 resulted in a significant decrease in phospho-ERK relative to the groups that received one conditioning trial (mean $=55 ; t_{(2)}=-3.7 ; p<$ 0.05). The group data (mean \pm SEM) shown in Figure $5 C$ represents the increased phosphorylation of ERK in the conditioned group relative to the unpaired controls detected with the antibody that recognized the dually phosphorylated forms of ERK1 and ERK2 (one-trial conditioning, mean $=6.5 \pm 2.6$; unpaired controls, mean $=2.2 \pm 0.5)$. The difference in phosphoERK between the conditioned groups $(n=4)$ and unpaired controls $(n=4)$ was statistically significant $\left(t_{(3)}=3.5 ; p<0.05\right)$. These findings are consistent with the previous studies that showed that conditioning increases the phosphorylation of the 44 and $42 \mathrm{kDa}$ phosphoproteins (ERK1 and ERK2) and that the increased phosphorylation is dependent on pairing light with 5-HT.

The analysis of one-trial in vitro conditioning indicates that ERK is phosphorylated and activated in groups receiving the conditioning trial of light and 5-HT compared with unpaired 
A

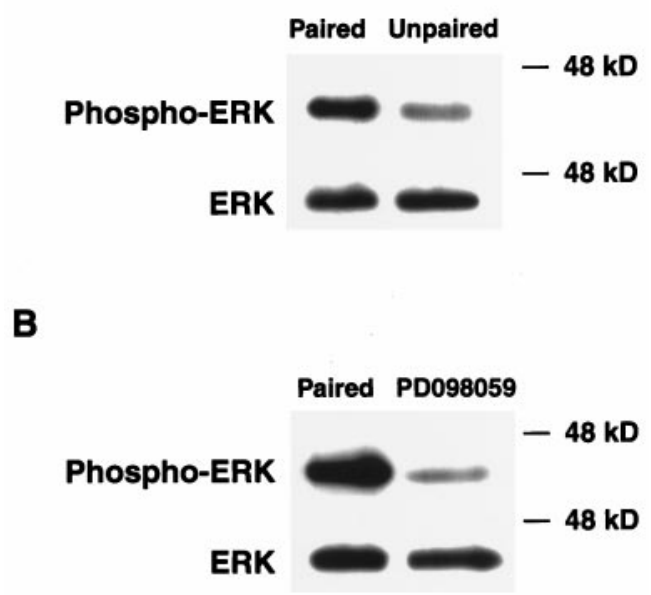

C

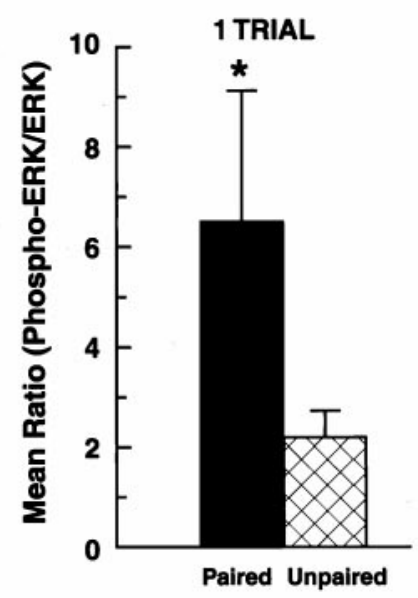

Figure 5. Western blot analysis of phosphorylation and activation of ERK. The preparations were processed for immunoblotting using the chemiluminescence detection method with antibodies recognizing nonphosphorylated and phosphorylated ERK1 and ERK2 or antibodies recognizing the dually phosphorylated forms of ERK1 and ERK2 (Promega). The antibody used for the immunoblotting studies stained a single band on immunoblots, consistent with the molecular weight of ERK. $A$, After one $10 \mathrm{~min}$ trial of light paired with 5-HT $\left(10^{-4} \mathrm{M}\right)$, an increased amount of phosphorylated ERK was detected compared with unpaired controls that received 10 min of unpaired light and 5-HT (see Materials and Methods). Neither paired light and 5-HT nor unpaired light and 5-HT changed the total amount of ERK detected with the antibody that recognized both phosphorylated and nonphosphorylated ERK. $B$, Pretreatment with PD098059 $30 \mathrm{~min}$ before one-trial conditioning blocks the phosphorylation of ERK detected after conditioning. $C$, Group data showing mean \pm SEM ratios of phospho-ERK/ERK for the groups that received one $10 \mathrm{~min}$ trial of light paired with 5-HT $(n=4)$ and the controls that received one $10 \mathrm{~min}$ trial of unpaired light and 5-HT $(n=4)$. One-trial conditioning resulted in a significant increase in ERK phosphorylation. ${ }^{*} p<0.05$.

controls. However, the potential relationship between ERK activity and behavior has not been established with the in vitro procedure. To address this issue we conditioned animals and established that conditioning produced behavioral phototactic suppression relative to pseudo-random controls that received the same number of explicitly unpaired CS and US presentations. The mean suppression ratios for the conditioned group $(n=17)$

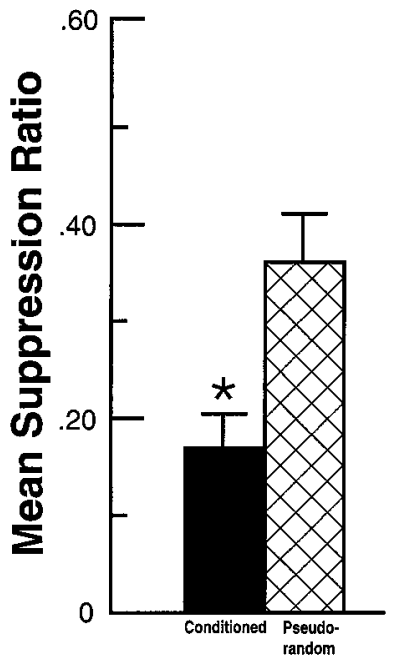

Figure 6. Group data depicting the mean \pm SEM suppression ratios for the conditioned group $(n=17)$ and the pseudo-random controls $(n=15)$. Conditioning produced a significant behavioral suppression in response to the CS after 10 or 15 conditioning trials. ${ }^{*} p<0.01$.

and pseudo-random controls $(n=15)$ tested 10 min after 10 or 15 conditioning trials is shown in Figure 6 . The behavioral analysis revealed that there were no significant differences between the groups receiving 10 trials or 15 trials, so the two groups were combined for the final analysis. As shown in Figure 6, conditioning produced a significant suppression of phototactic behavior (mean $=0.18 \pm 0.04)$ compared with the pseudo-random controls $\left(\right.$ mean $\left.=0.36 \pm 0.06 ; t_{(30)}=2.5 ; p<0.01\right)$. After conditioning and behavioral testing, preparations were prepared for analysis of phosphorylated ERK. Examples of the Western blot analysis of ERK in the eyes and proximal optic nerve preparations from the conditioned and pseudo-random controls is shown in Figure $7 A$. As shown in the Western blots of Figure $7 A$, phospho-ERK was greater for the conditioned group compared with the pseudorandom controls. However, neither procedure changed the total amount of ERK detected with the antibody that recognized both phosphorylated and nonphosphorylated ERK (Fig. 7 $A$ ). The statistical analysis of the group data shown in Figure $7 B$, consisting of ratios of phospho-ERK/ERK from conditioned preparations $($ mean $=1.6 \pm 0.15 ; n=5)$ and pseudo-random controls $($ mean $=$ $1.3 \pm 0.10 ; n=5)$, revealed that conditioning resulted in a significant increase in phosphorylated $\operatorname{ERK}\left(t_{(4)}=3.4 ; p<0.02\right)$ (Fig. $7 B$ ). These results provide evidence that behavioral conditioning results in a significant increase in the phosphorylation of ERK that can be detected shortly after behavioral testing.

\section{DISCUSSION}

The major findings from our studies are that a one-trial in vitro conditioning procedure results in the increased phosphorylation of ERK, as detected by ${ }^{32} \mathrm{PO}_{4}$ labeling and antibodies recognizing the dually phosphorylated forms of ERK1 and ERK2 and an increase in ERK activity. In addition, inhibition of the ERK activator MEK1 blocks increased phosphorylation of ERK1 and ERK2, as detected by ${ }^{32} \mathrm{PO}_{4}$ labeling and antibodies that recognize phospho-ERK1 and -ERK2. Finally, we have provided evidence that classical conditioning that produces significant behavioral suppression results in a significant increase in ERK phosphorylation compared with pseudo-random controls. 
A

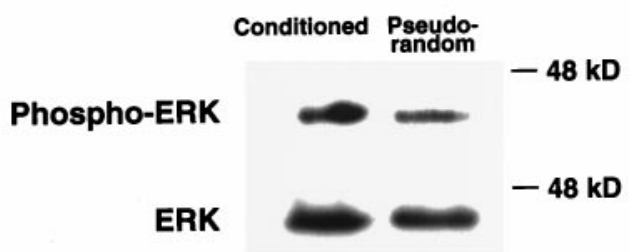

B

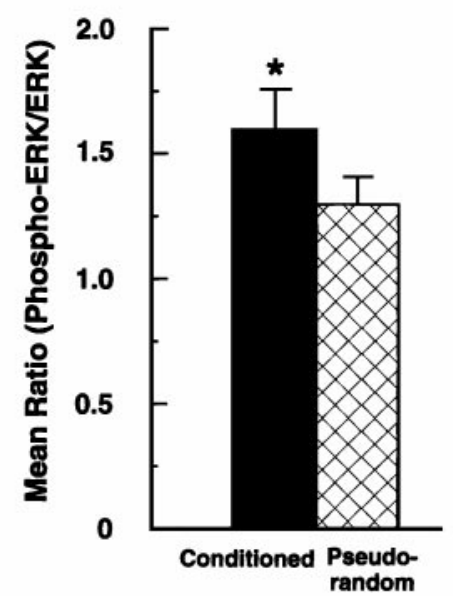

Figure 7. Western blot analysis of phosphorylation of ERK after 10 or 15 conditioning trials compared with pseudo-random controls. $A$, After 10 conditioning trials the amount of phosphorylated ERK was greater than the pseudo-random control group. Neither conditioning nor the control procedure changed the total amount of ERK detected with the antibody that recognized both phosphorylated and nonphosphorylated ERK. $B$, Group data showing the mean \pm SEM ratio of phospho-ERK/ERK for the conditioned group $(n=5)$ and the pseudo-random controls $(n=5)$. The conditioned group $($ mean $=1.6 \pm 0.15)$ showed a significant increase in phosphorylated ERK compared with the controls (mean $=1.3 \pm 0.10)$. ${ }^{*} p<0.02$.

\section{Signal transduction in the CS pathway}

Studies of the nervous system in general and specifically the CS pathway in conditioned Hermissenda have documented the role of PKC in enhancement of synaptic efficacy, cellular excitability, and classical conditioning (Farley and Auerbach, 1986; Neary et al., 1986; Alkon et al., 1988; Matzel et al., 1990; Crow et al., 1991; Crow and Forrester, 1993; Schuman and Clark, 1994; Frysztak and Crow, 1997). In addition, PKC plays a role in several examples of cellular and synaptic plasticity in both vertebrates and invertebrates (Akers et al., 1986; Malinow et al., 1989; Braha et al., 1990; Sacktor and Schwartz, 1990; Sugita et al., 1992). In Hermissenda, PKC inhibitors have been shown to block the induction of short-term plasticity (Matzel et al., 1990; Crow et al., 1991; Crow and Forrester, 1993) and reverse the expression of established plasticity in conditioned animals (Farley and Schuman, 1991; Frysztak and Crow, 1997). Moreover, downregulation of PKC has also been shown to be effective in blocking the induction of short-term plasticity (Crow et al., 1991; Crow and Forrester, 1993). However, long-term enhancement produced by one-trial conditioning does not depend on the activation of PKC (see next section).

\section{Independence of short- and long-term plasticity}

Recent studies of Hermissenda have shown that short- and longterm enhancement may be independent parallel processes, because they can be dissociated based on the role of mRNA synthesis, protein synthesis, and the contribution of protein kinase $\mathrm{C}$ (Crow and Forrester, 1990, 1991, 1993; Crow et al., 1997). Downregulation of $\mathrm{PKC}$ and preconditioning treatment with kinase inhibitors block the induction of short-term enhancement, although long-term enhancement can still be expressed (Crow and Forrester, 1993). This finding suggests that additional signaling pathways are engaged to support the consolidation of long-term memory in Hermissenda. ERK, a member of the mitogenactivated protein kinase family, is an attractive candidate for contributing to long-term enhancement. The ERK cascades are highly conserved, being found in all eukaryotic organisms (Robinson and Cobb, 1997). MAPK cascades are a series of cytosolic enzymes that can transmit extracellular signals to the nucleus (for review, see Neary, 1997). These cascades consist of at least three protein kinases that are activated sequentially: a MAPK kinase kinase such as Raf-1 activates a MAPK kinase such as MEK1, which in turn activates a MAPK such as ERK. The activated ERK can translocate to the nucleus (Chen et al., 1992; Lenormand et al., 1993), where it can phosphorylate or induce transcription factors leading to the activation of genes and the expression of proteins needed for differentiation or proliferation. In addition to nuclear targets, ERK can phosphorylate membrane, cytoskeletal and cytoplasmic proteins and thus may be involved in other cellular functions (Minshull et al., 1994), including the regulation of ion channels (Adams et al., 1997). Growth factors activate the ERK cascade by means of a well established sequence of receptor autophosphorylation and protein-protein interactions, leading to stimulation of Raf-1. G-protein-coupled receptors (GPCRs), such as serotonin receptors (Hershenson et al., 1995; Launay et al., 1996), can also activate the ERK cascade. Soluble protein kinases such as Src (Chen et al., 1994; Luttrell et al., 1996), PKC (Wang et al., 1992; van Biesen et al., 1996), and Pyk2 (Lev et al., 1995) often link GPCRs to the ERK cascade. PKC (Nishizuka, 1995) and Pyk2 (Lev et al., 1995) can be activated by increases in intracellular calcium, thereby linking calcium-dependent signaling pathways to the ERK cascade. In this manner, activation of ERK by these protein kinases may play a role in short- and/or long-term calcium-dependent functions in the CNS. Interestingly, ERK has recently been shown to be involved in LTP (English and Sweatt, 1996) and long-term facilitation of cultural Aplysia neurons (Martin et al., 1997). It was recently reported that procedures that produce long-term facilitation result in the translocation of MAPK in the presynaptic, but not postsynaptic neurons in Aplysia sensorimotor co-cultures. In addition, MAPK is required for long-term but not short-term facilitation (Martin et al., 1997). In hippocampal slices the p42 MAPK isoform, but not the p44 MAPK isoform, is activated in CA1 after LTP induction. The ERK signaling cascade is attractive in Hermissenda plasticity because upstream components may involve the activation of PKC and a MEK activator such as Raf. This would provide for the convergence point within the signaling pathway to support input from the CS and US pathways. Alternatively, the PKC and ERK cascade may represent two independent parallel pathways that support short- and long-term memory for Pavlovian conditioning. Our findings indicate that ERK is 
phosphorylated and active soon after one-trial and multi-trial conditioning. However, it is not known in Hermissenda, or in other species, that ERK phosphorylation is uniquely responsible for long-term memory.

\section{Multi-trial Pavlovian conditioning}

The one-trial conditioning procedure was shown to result in long-term ( $24 \mathrm{hr}$ ) behavioral suppression, although tests of behavioral changes immediately after the conditioning trial could not be performed (Crow and Forrester, 1986). It was shown previously that 10 conditioning trials did not result in pairing specific behavioral suppression when animals were tested 1 or 30 min after conditioning (Crow, 1983). In the present study, the CS duration and inter-trial-interval were modified from the procedures used in the earlier study to produce the most efficacious conditions for the expression of Pavlovian conditioning after a few conditioning trials.

\section{Excitability changes and Pavlovian conditioning}

Studies of cellular correlates of Pavlovian conditioning in Hermissenda have identified both changes in synaptic efficacy (Frysztak and Crow, 1994, 1997) and changes in excitability of cells in the CS pathway (Crow and Alkon, 1980; Crow, 1985; Frysztak and Crow, 1993, 1997; Farley and Han, 1997). Indeed, conditioned enhancement of excitability appears to be a general characteristic of both vertebrate and invertebrate Pavlovian conditioning. Excitability changes in hippocampal pyramidal neurons have been detected in vitro after Pavlovian conditioning (Moyer et al., 1996; Thompson et al., 1996). The cellular correlates of shortand long-term enhancement after one-trial conditioning of Hermissenda involve changes in excitability. It is interesting to note that the Kv4.2 channel, a voltage-activated potassium channel localized to dendrites in the hippocampus, is a substrate for MAPK phosphorylation (Adams et al., 1997). The reduction in the conductance of an A-type $\mathrm{K}^{+}$channel in Hermissenda has been proposed as a mechanism of Pavlovian conditioning (Alkon et al., 1982). It is therefore intriguing that activation of the ERK cascade could potentially be regulating diverse $\mathrm{K}^{+}$conductances that have profound effects on cellular excitability.

\section{REFERENCES}

Adams JP, Anderson AE, Johnston D, Pfaffinger PJ, Sweatt JD (1997) Kv4.2: a novel substrate for MAP kinase phosphorylation. Soc Neurosci Abstr 23:1176.

Akers RF, Lovinger DM, Colley PA, Linden DJ, Routenberg A (1986) Translocation of protein kinase $\mathrm{C}$ activity may mediate hippocampal long-term potentiation. Science 231:587-589.

Alkon DL, Fuortes MGF (1972) Responses of photoreceptors in Hermissenda. J Gen Physiol 60:631-649.

Alkon DL, Lederhendler I, Shoukimas JJ (1982) Primary changes of membrane currents during retention of associative learning. Science 215:693-695.

Alkon DL, Naito S, Kubota M, Chen C, Bank B, Smallwood J, Gallant P, Rasmussen H (1988) Regulation of Hermissenda $\mathrm{K}^{+}$channels by cytoplasmic and membrane-associated C-kinase. J Neurochem 51:903-917.

Bailey CH, Bartsch D, Kandel ER (1996) Toward a molecular definition of long-term memory storage. Proc Natl Acad Sci USA 93:13445-13452.

Braha O, Dale N, Hochner B, Klein M, Abrams TW, Kandel ER (1990) Second messengers involved in the two processes of presynaptic facilitation that contribute to sensitization and dishabituation in Aplysia sensory neurons. Proc Natl Acad Sci USA 87:2040-2044.

Chen RH, Sarnecki C, Blenis J (1992) Nuclear localization and regulation of erk- and rsk-encoded protein kinases. Mol Cell Biol 12:915-927.

Chen YH, Pouyssegur J, Courtneidge SA, Van Obberghen-Schilling E (1994) Activation of Src family kinase activity by G protein-coupled thrombin receptor in growth-responsive fibroblasts. J Biol Chem 269:27372-27377.

Crow TJ (1983) Conditioned modification of locomotion in Hermissenda crassicornis: analysis of time-dependent associative and nonassociative components. J Neurosci 12:2621-2628.

Crow T (1985) Conditioned modification of phototactic behavior in Hermissenda. II. Differential adaptation of B-photoreceptors. J Neurosci 5:215-223.

Crow T, Alkon DL (1978) Retention of an associative behavioral change in Hermissenda. Science 201:1239-1241.

Crow T, Alkon DL (1980) Associative behavioral modification in Hermissenda: cellular correlates. Science 209:412-414.

Crow T, Forrester J (1986) Light paired with serotonin mimics the effect of conditioning on phototactic behavior in Hermissenda. Proc Natl Acad Sci USA 83:7975-7978.

Crow T, Forrester J (1990) Inhibition of protein synthesis blocks longterm enhancement of generator potentials produced by one-trial in vivo conditioning in Hermissenda. Proc Natl Acad Sci USA 87:4490-4494.

Crow T, Forrester J (1991) Light paired with serotonin in vivo produces both short- and long-term enhancement of generator potentials of identified B-photoreceptors in Hermissenda. J Neurosci 11:608-617.

Crow T, Forrester J (1993) Down-regulation of protein kinase C and kinase inhibitors dissociate short- and long-term enhancement produced by one-trial conditioning of Hermissenda. J Neurophysiol 69:636-641.

Crow T, Offenbach N (1983) Modification of the initiation of locomotion in Hermissenda: behavioral analysis. Brain Res 271:301-310.

Crow T, Forrester J, Williams M, Waxham MN, Neary JT (1991) Downregulation of protein kinase $\mathrm{C}$ blocks 5-HT-induced enhancement in Hermissenda B-photoreceptors. Neurosci Lett 12:107-110.

Crow T, Siddiqi V, Zhu Q, Neary JT (1996) Time-dependent increase in protein phosphorylation following one-trial enhancement in Hermissenda. J Neurochem 66:1736-1741.

Crow T, Siddiqi V, Dash PK (1997) Long-term enhancement but not short-term in Hermissenda is dependent upon mRNA synthesis. Neurobiol Learn Mem 58:343-350.

DeZazzo J, Tully T (1995) Dissection of memory formation: from behavioral pharmacology to molecular genetics. Trends Neurosci 18:212-218.

Dudley DT, Pang L, Decker SJ, Bridge AJ, Saltiel AR (1995) A synthetic inhibitor of the mitogen-activated protein kinase cascade. Proc Natl Acad Sci USA 92:7686-7689.

English JD, Sweatt JD (1996) Activation of p42 mitogen-activated protein kinase in hippocampal long-term potentiation. J Biol Chem 271:24324-24332.

Farley J, Auerbach S (1986) Protein kinase C activation induces conductance changes in Hermissenda photoreceptors like those seen in associative learning. Nature 319:220-223.

Farley J, Han Y (1997) Ionic basis of learning-correlated excitability changes in Hermissenda type A photoreceptors. J Neurophysiol 77:1861-1888.

Farley J, Schuman E (1991) Protein kinase C inhibitors prevent induction and continued expression of cell memory in Hermissenda type B photoreceptors. Proc Natl Acad Sci USA 88:2016-2020.

Frystak RJ, Crow T (1993) Differential expression of correlates of classical conditioning in identified medial and lateral type A-photoreceptors of Hermissenda. J Neurosci 13:2889-2897.

Frysztak RJ, Crow T (1994) Enhancement of type B and A photoreceptor inhibitory synaptic connections in conditioned Hermissenda. J Neurosci 14:1245-1250.

Frysztak RJ, Crow T (1997) Synaptic enhancement and enhanced excitability in presynaptic and postsynaptic neurons in the conditioned stimulus pathway of Hermissenda. J Neurosci 17:4426-4433.

Görg A (1991) Two-dimensional electrophoresis. Nature 349:545-546.

Görg A, Postel W, Günther S (1988) The current state of twodimensional electrophoresis with immobilized $\mathrm{pH}$ gradients. Electrophoresis 9:531-546.

Hershenson MB, Chao TS, Abe MK, Gomes I, Kelleher MD, Solway J, Rosner MR (1995) Histamine antagonizes serotonin and growth factor-induced mitogen-activated protein kinase activation in bovine tracheal smooth muscle cells. J Biol Chem 270:19908-19913.

Launay JM, Birrauz G, Bondoux D, Callebert J, Choi DS, Loric S, Maroteaux L (1996) Ras involvement in signal transduction by the serotonin 5-HT2B receptor. J Biol Chem 271:3141-3147.

Lenormand P, Sardet C, L-Pages G, L-Allemain G, Brunet A, Pouysse- 
gur J (1993) Growth factors induce nuclear translocation of MAP kinases (p42 ${ }^{\text {mapk }}$ and $\mathrm{P} 44^{\mathrm{mapk}}$ ) but not of their activator MAP kinase (p45 mapkk) in fibroblasts. J Cell Biol 122:1079-1088.

Lev S, Moreno H, Martinez R, Canoll P, Peles E, Musacchio JM, Plowman GD, Rudy B, Schlessinger J (1995) Protein tyrosine kinase PYK2 involved in $\mathrm{Ca}^{2+}$-induced regulation of ion channel and MAP kinase functions. Nature 376:737-745.

Luttrell LM, Hawes BE, van Biesen T, Luttrell DK, Lansing TJ, Lefkowitz RJ (1996) Role of c-Src-tyrosine kinase in G protein-coupled receptor- and Gbetagamma subunit-mediated activation of mitogenactivated protein kinases. J Biol Chem 271:19443-19450.

Malinow R, Schulman H, Tsien RW (1989) Inhibition of post-synaptic PKC or CaMKII blocks induction but not expression of LTP. Science 245:862-866.

Martin KC, Michael K, Rose JC, Barad M, Casadio A, Zhu H, Kandel ER (1997) MAP kinase translocates into the nucleus of the presynaptic cell and is required for long-term facilitation in Aplysia. Neuron 18:899-912.

Matzel LD, Lederhendler II, Alkon DL (1990) Regulation of a shortterm associative memory by calcium-dependent protein kinase. J Neurosci 10:2300-2307.

Minshull J, Sun H, Tonks NK, Murray AW (1994) A MAP kinasedependent spindle assembly checkpoint in Xenopus egg extracts. Cell 79:475-486.

Moyer JR, Thompson LT, Disterhoft JF (1996) Trace eyeblink conditioning increases CA1 excitability in a transient and learning-specific manner. J Neurosci 16:5536-5546.

Neary JT (1997) MAPK cascades in cell growth and death. News Physiol Sci 12:286-293.

Neary JT, Zhu Q (1994) ATP receptor signaling via MAP kinase. NeuroReport 5:1618-1620.

Neary JT, Crow T, Alkon DL (1981) Change in a specific phosphoprotein band following associative learning in Hermissenda. Nature 293:658-660.
Neary JT, Naito S, DeWeer A, Alkon DL (1986) $\mathrm{Ca}^{2+} /$ diacylglycerolactivated, phospholipid-dependent protein kinase in the Hermissenda CNS. J Neurochem 47:1405-1411.

Nishizuka Y (1995) Protein kinase C and lipid signaling for sustained cellular responses. FASEB J 9:484-496.

Peterson GL (1983) Determination of total protein. Methods Enzymol 91:95-119.

Robinson MJ, Cobb MH (1997) Mitogen-activated protein kinase pathways. Curr Opin Cell Biol 9:180-186.

Sacktor TC, Schwartz JH (1990) Sensitizing stimuli cause translocation of protein kinase C in Aplysia sensory neurons. Proc Natl Acad Sci USA 87:2036-2039.

Schuman EM, Clark GA (1994) Synaptic facilitation at connections of Hermissenda type B-photoreceptors. J Neurosci 14:1613-1622.

Sugita S, Goldsmith JR, Baxter DA, Byrne JH (1992) Involvement of protein kinase $\mathrm{C}$ in serotonin-induced spike broadening and synaptic facilitation in sensorimotor connections of Aplysia. J Neurophysiol 68:643-651.

Thompson LT, Moyer JR, Disterhoft JF (1996) Transient changes in excitability of rabbit CA3 neurons with a time-course appropriate to support memory consolidation. J Neurophysiol 76:1836-1849.

Van Biesen T, Hawes BE, Raymond JR, Luttrell LM, Koch WJ, Lefkowitz RJ (1996) Go-protein alpha-subunits activate mitogen-activated protein kinase via a novel protein kinase $\mathrm{C}$-dependent mechanism. J Biol Chem 271:1266-1269.

Wang Y, Simonson MS, Pouyssegur J, Dunn MJ (1992) Endothelin rapidly stimulates mitogen-activated protein kinase activity in rat mesangial cells. Biochem J 287:589-594.

Xue-Bian JJ, Siddiqi V, Crow T (1997a) An inhibitor of the MAP kinase cascade inhibits protein phosphorylation detected after one-trial conditioning of Hermissenda. FASEB J 11:A34.

Xue-Bian JJ, Siddiqi V, Crow T (1997b) Inhibitors of MEK1 and PKC block protein phosphorylation associated with short- and long-term enhancement in Hermissenda. Soc Neurosci Abstr 23:1235. 